\title{
Significance of exoenzymatic activities in the ecology of brackish water: measurements by means of methylumbelliferyl-substrates
}

\author{
Hans-Georg Hoppe
}

Institut für Meereskunde an der Universität Kiel, D-2300 Kiel, Düsternbrooker Weg 20, Federal Republic of Germany

\begin{abstract}
Exoenzymatic activity is an important factor for macromolecular substrate turnover in marine environments. It serves as a balance of the DOC pool and supplies microheterotrophs with easily degradable organic substrates. Velocities of hydrolysis of glucosides, protein-like compounds, glucosaminides and organic phosphorous compounds and hydrolyzation rates of naturally occurring substrate analogues were measured by means of fluorogenic methylumbelliferyl (MUF)-compounds. Field observations of exoenzymatic activity together with the measurements of other bacterial activity parameters were derived from 2 eutrophied Baltic Sea fjords and adjacent offshore waters. Protease activity was dominant in all water samples. $\alpha$-D-glucosidase and glucosaminidase activities showed strongest variations between fjords and offshore waters. These enzymes appear suitable as indicators for organic pollution and eutrophication. A preliminary combination experiment with MUF-compounds and radioactively labelled substrates exhibited a discrepancy between the amount of substrate hydrolyzed by exoenzymes and the incorporation of this substrate by bacteria. This may give an indication towards medium-scale changes in the DOC pool and the mode of equilibration of small molecules and macromolecules in the DOC pool.
\end{abstract}

\section{INTRODUCTION}

Autochthonous organic materials in the sea originate from particulate living biomass. Dissolved organic compounds, especially those from phyto- and zooplankton, are lost via exudation and enter the DOC pool (Derenbach and Williams, 1974; Berman and Holm-Hansen, 1974; Eppley et al., 1981; Wolter, 1982). The particulate fraction is partly incorporated by secondary producers. The remaining part is finally converted to detritus and is subject to further decomposition. This dynamic process, important as it is for the turnover and continuous supply of low-molecular substrates, is still poorly understood. During the conversion of living biomass to non-living detritus, autolytic enzymes from the organisms themselves will play a role in the initial destruction of certain cell compounds. In successive decomposition processes the enzymatic capacity of bacteria is certainly involved. For culturable marine periphytic bacteria a secretion of hydrolytic enzymes (protease, $\alpha$-amylase, $\beta$-Dglucosidase) has already been detected (Corpe and Winters, 1972). Burns (1980) developed a theory about the mode of exoenzymatic action, whereby microbial adhesion to soil surfaces is a key step. Potentials for the decomposition of particulate organic matter in natural waters and sediments have been obtained by using particulate model substrates such as hide powder azure or $\alpha$-amylopectin azure (Little et al., 1979, Meyer-Reil, 1981). Depending on the kind of substrate and enzymes involved, step-wise destruction of particles results in the accumulation of soluble monomers, oligomers or macromolecules. Some of these compounds are ready for incorporation by bacteria while others undergo further enzymatic reduction.

The process of enzymatic action on oligomers, which include a special bonding and are not ready for bacterial incorporation, is the main subject of this investigation. Exoenzymatic activities were measured by means of methylumbelliferyl (MUF)-substrates such as MUF$\alpha$-D-glucopyranoside, MUF- $\beta$-D-glucoside, MUF-Nacetyl glucosaminide, MUF-phosphate and L-leucinemethylcumarinyl amide. At the present stage of investigation it is not known to what extent these substrates are representative of naturally occurring substances of the same categories or whether the specificity of enzymes acting on them has a broad or narrow spectrum. Nevertheless, the addition of naturally occurring com- 
pounds produced a competitive inhibition of the enzymatic decomposition of MUF-substrates. This shows that the enzymatic activities which are measured with this method have a close relationship to processes of substrate turnover in nature. This is also emphasized by their strong correlation with certain microbiological parameters. The method is sensitive enough to measure the maximal activity of the enzymes present as well as the hydrolyzation rate of natural substrates involved in the specific processes. Even at low temperature and under oligotrophic conditions it provides reliable measurements of exoenzymatic activity on a variety of the most common classes of substrates occurring in natural waters.

The method was applied to winter and early springbloom situations in Baltic Sea fjords of different degrees of eutrophication (Schlei, Kieler Förde). Additional measurements of chlorophyll, primary production, bacteria substrate incorporation, bacteria production, various environmental parameters and experiments with fractionated filtration serve as support for the interpretation of the results.

The main ecological advancement of this method is that it offers a tool to estimate the extent of the continual supply of low-molecular substrates utilizable by microheterotrophs.

\section{MATERIAL AND METHODS}

Chemical, physical und planktological analysis of water samples were conducted according to standard methods. Colony-forming bacteria were isolated on ZoBell agar of appropriate salinities. The total number of bacteria and bacteria biomass was estimated by epifluorescence microscopy (Zimmermann and MeyerReil, 1974). The uptake of ${ }^{14} \mathrm{C}$-glucose by microheterotrophs was investigated in time series after Meyer-Reil et al. (1980). Bacteria production via ${ }^{3} \mathrm{H}-$ thymidine incorporation in DNA was measured according to the procedure suggested by Fuhrman and Azam (1980).

The method developed for exoenzymatic analysis was adapted from biochemical techniques (Leaback and Walker, 1961; Rosenthal and Saifer, 1973; Taylor et al., 1977) and from soil lipase measurements by Pancholy and Lynd $(1971,1972)$. The mechanism of the exoenzymatic reduction of MUF-substrates used in this approach is demonstrated with MUF- $\beta$-D-glucopyranoside (Fig. 1).

The standard procedure was as follows: Water samples were collected with sterilized equipment; $50 \mathrm{ml}$ subsamples were filled into $100 \mathrm{ml}$ glass bottles and supplemented with MUF-substrate (MUF- $\alpha-D-$ glucopyranoside, MUF- $\beta$-D-glucopyranoside, MUF-Nacetyl-glucosaminide, MUF-phosphate or MUF-Lleucine or MUF for calibration, all of which are commercially obtainable from Serva Feinbiochemica, Heidelberg or Sigma Chemie, München (FRG).

Prior to their addition to the sample, the MUF-substrates were dissolved in Methylcellosolve $(2 \mathrm{ml}$ Methylcellosolve plus $10^{-2} \mathrm{mM}$ MUF-substrate). Aliquots of the stock solution ( 5 to $400 \mu \mathrm{l}$ ) were added to the water samples yielding final concentrations of MUF-substrates of 0.5 to $40 \mu \mathrm{M}$. Fluorescence of the samples was measured after various length of incubation (usually $0,3,6$, and $9 \mathrm{~h}$ ). For fluorescence measurements exactly $2.5 \mathrm{ml}$ water were pipetted from the bottles into a $1 \mathrm{~cm}$ quartz cuvette and $0.2 \mathrm{ml}$ of buffer (pH 10, Merck) were added. Fluorescence intensity was then read at $455 \mathrm{~nm}$ under $365 \mathrm{~nm}$ excitation in a

Controls were run with water samples boiled for $20 \mathrm{~min}$ in a water bath prior to addition of the MUFsubstrates. Exoenzymatic activity is expressed in terms of velocity of hydrolysis $\left(\mu \mathrm{g} \mathrm{C} 1^{-1} \mathrm{~h}^{-1}\right.$ or $\mu \mathrm{g} \mathrm{PO}_{4}{ }^{-3} 1^{-1}$ $\mathrm{h}^{-1}$ in the case of MUF-phosphate and hydrolyzation rate $\left(\% \mathrm{~h}^{-1}\right)$ of the naturally occurring substrate analogues.

Precautions: MUF-substrates, MUF and stock solutions were stored at deep-freeze temperatures of $-20^{\circ} \mathrm{C}$, and all incubations were performed in the dark.

\section{RESULTS}

\section{MUF calibration curve}

The MUF calibration curve was established with brackish water from the Kiel Fjord according to the described standard procedure. Repeated measurement after $24 \mathrm{~h}$ incubation in the dark revealed exactly the same values indicating the stability of the fluorescent tracer in this natural environment (Fig. 2). In waters with great differences in turbidity the establishment of a calibration curve with a reduced number of MUF concentrations for each type of water is recommended.

Fig. 1. The non-fluorescent substrate, MUF- $\beta-D-$ glucopyranoside, is split by the exoenzyme $\beta$-Dglucosidase. Glucose is liberated from the compound and the equimolar concentration of free MUF is measured at $445 \mathrm{~nm}$ under $364 \mathrm{~nm}$ exitation in a spectrofluorimeter
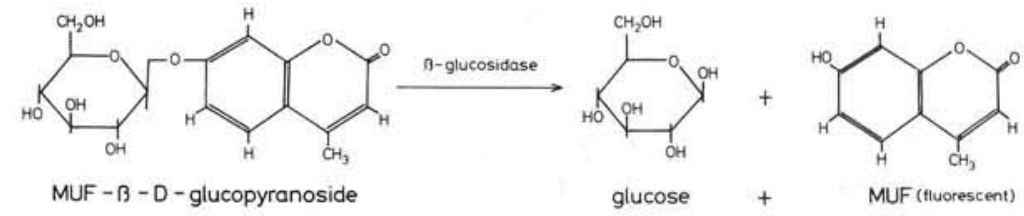


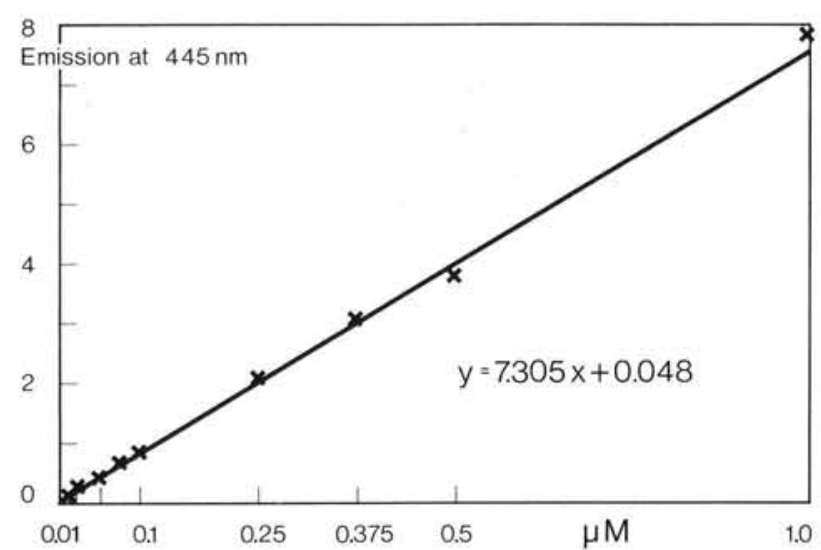

Fig. 2. MUF-calibration curve. Fluorescence emission of low MUF-concentrations as they may occur in enzymatic decomposition progresses of MUF-substrates; $r=0.999$

\section{Influence of methylcellosolve on exoenzymatic activity}

Methylcellosolve (ethylene glycol monomethylether, EM) was used as a solvent for MUF and the MUF-substrates. Since it is a highly aggressive agent its influence on exoenzymatic activities was investigated at various concentrations. The experiment was performed with 3 MUF-substrates $(10 \mu \mathrm{M})$ and methylcellosolve supplements of up the $800 \mu \mathrm{l}$ per $50 \mathrm{ml}$ water sample which is 2 times that of the highest concentration used in standard experiments (Table 1).

The results show no clear tendency of an inhibitory or excitatory effect of the solvent on enzymatic activities, thus, the influence of the solvent was considered unimportant.

\section{Competitive inhibition}

To demonstrate the validity of this method for use in exoenzymatic studies in natural waters the competitive inhibition of MUF-substrates by naturally occurring substrate analogues was investigated. Maltose was used as a competitive inhibitor of MUF- $\alpha$-D-glucoside,

Table 1. Effect of the solvent, ethylene glycol monomethylether (EM), on exoenzymatic activities (velocity of hydrolysis, $\mu \mathrm{g}$ substrate $\mathrm{l}^{-1} \mathrm{~h}^{-1}$

\begin{tabular}{|cccc|}
\hline & $\begin{array}{c}\text { MUF- } \alpha-D- \\
\text { gluco- } \\
\text { pyranoside }\end{array}$ & $\begin{array}{c}\text { MUF- } \\
\text { glucos- } \\
\text { aminide }\end{array}$ & $\begin{array}{c}\text { MUF- } \\
\text { phos- } \\
\text { phate }\end{array}$ \\
\hline No additional EM & 0.856 & 3.37 & 6.21 \\
$+100 \mu \mathrm{l} \mathrm{EM}$ & 0.955 & 3.23 & 8.97 \\
$+200 \mu \mathrm{l}$ EM & 1.055 & 3.08 & 8.68 \\
$+800 \mu \mathrm{l}$ EM & 0.955 & 2.59 & 7.30 \\
\hline
\end{tabular}

as was cellobiose for MUF- $\beta$-D-glucopyranoside, serum albumin for MUF-L-leucine, and phosphogluconic acid for MUF-phosphate (Table 2).

Table 2. Competitive inhibition of exoenzymatic activity as demonstrated by increases of the hydrolyzation time. The first figure of a column gives the hydrolyzation time of a certain amount of MUF-substrate plus the amount of natural substrate analogue $\left(\mathrm{S}_{n}\right)$ in a water-sample at low in situ temperature $\left(4^{\circ} \mathrm{C}\right)$. The influence of different amounts of substrate analogues added to the sample is given by the following figures

\begin{tabular}{|c|c|}
\hline Substrate & $\begin{array}{l}\text { Hydrolyzation } \\
\text { time }(\mathrm{h})\end{array}$ \\
\hline $10 \mu \mathrm{M}$ MUF- $\alpha$-D-glucopyranoside $+\mathrm{S}_{\mathrm{n}}$ & 6480 \\
\hline$+10 \mu \mathrm{M}$ maltose & 8097 \\
\hline$+50 \mu \mathrm{M}$ maltose & 16207 \\
\hline$+100 \mu \mathrm{M}$ maltose & 32468 \\
\hline $10 \mu \mathrm{M}$ MUF- $\beta$-D-glucopyranoside $+\mathrm{S}_{\mathrm{n}}$ & 2093 \\
\hline$+10 \mu \mathrm{M}$ cellobiose & 2254 \\
\hline$+50 \mu \mathrm{M}$ cellobiose & 2442 \\
\hline$+100 \mu \mathrm{M}$ cellobiose & 3256 \\
\hline $5 \mu \mathrm{M}$ MUF-phosphate $+\mathrm{S}_{\mathrm{n}}$ & 455 \\
\hline$+5 \mu \mathrm{M}$ phosphogluconic acid & 581 \\
\hline$+10 \mu \mathrm{M}$ phosphogluconic acid & 633 \\
\hline$+20 \mu \mathrm{M}$ phosphogluconic acid & 704 \\
\hline $5 \mu \mathrm{M}$ MUF-leucine $+\mathrm{S}_{\mathrm{n}}$ & 301 \\
\hline$+5 \mu \mathrm{M}$ serum albumin & 310 \\
\hline$+10 \mu \mathrm{M}$ serum albumin & 315 \\
\hline$+20 \mu \mathrm{M}$ serum albumin & 325 \\
\hline$+50 \mu \mathrm{M}$ serum albumin & 366 \\
\hline
\end{tabular}

Shortest hydrolyzation times were found for proteases (which are able to decompose MUF-L-leucine), followed by MUF-phosphatases, $\beta$-D-glucosidases, and finally $\alpha$-D-glucosidases. This pattern has been observed in most of the water samples investigated from the brackish water Kiel Bight area. A prolongation of the hydrolyzation time was noted in all cases when a substrate analogue was added to the water samples. Relations between hydrolyzation times do not exactly follow the molarities of added substrate analogues. However, this cannot be expected because exoenzymatic activities will increase with increasing substrate concentrations up to a certain point of saturation. Competitive inhibition seems to be very obvious for maltose as a substrate analogue of MUF- $\alpha-D-$ glucopyranoside and relatively weak for serum albumin as a competitive inhibitor of proteases. But since the influence of $S_{n}$ on the hydrolyzation time cannot be considered from these experiments, they confirm only the presence of competitive inhibition. Additional experiments to obtain the full kinetic parameters of competitive inhibition were not totally satisfactory. 
Table 3. Liberation of substrate from MUF-substrate $\left(\mu \mathrm{g}\right.$ substrate $\mathrm{1}^{-1} \mathrm{~h}^{-1}$ ) in sample water and in dilutions of sample water with boiled sample water

\begin{tabular}{|c|c|c|c|c|c|c|c|}
\hline \multirow[t]{2}{*}{ Sample } & \multirow{2}{*}{$\begin{array}{l}\text { Sample water } \\
\text { after dilution } \\
\%\end{array}$} & \multicolumn{2}{|c|}{$\begin{array}{l}\text { MUF- } \alpha \text {-D-gluco- } \\
\text { pyranoside }\end{array}$} & \multicolumn{2}{|c|}{$\begin{array}{c}\text { MUF- } \\
\text { glucosaminide }\end{array}$} & \multicolumn{2}{|c|}{$\begin{array}{c}\text { MUF- } \\
\text { phosphate }\end{array}$} \\
\hline & & $\mu \mathrm{g} \mathrm{l}^{-1} \mathrm{~h}^{-1}$ & $\%$ & $\mu \mathrm{g} \mathrm{l}^{-1} \mathrm{~h}^{-1}$ & $\%$ & $\mu \mathrm{g} \mathrm{l}^{-1} \mathrm{~h}^{-1}$ & $\%$ \\
\hline $50 \mathrm{ml}$ sample & 100 & 0.69 & 100 & 2.27 & 100 & 2.66 & 100 \\
\hline $\begin{array}{l}25 \mathrm{ml} \text { sample }+ \\
25 \mathrm{ml} \text { boiled sample }\end{array}$ & 50 & 0.28 & 41 & 1.02 & 45 & 1.29 & 48 \\
\hline $\begin{array}{l}10 \mathrm{ml} \text { sample }+ \\
40 \mathrm{ml} \text { boiled sample }\end{array}$ & 20 & 0.11 & 16 & 0.33 & 15 & 0.59 & 22 \\
\hline $\begin{array}{l}5 \mathrm{ml} \text { sample }+45 \mathrm{ml} \\
\text { boiled sample }\end{array}$ & 10 & 0.04 & 6 & 0.21 & 9 & 0.22 & 8 \\
\hline
\end{tabular}

\section{Dependency of enzymatic activity on the abundance of living sources}

If decomposition of MUF-substrate is exclusively a function of free dissolved enzymes and of living organisms and not of other physical or chemical effects, its rate should correspond directly to the dilution rate of a water sample with inactivated sample water. For this purpose successively decreasing amounts of natural water were mixed with increasing amounts of natural water boiled for $20 \mathrm{~min}$ in a waterbath. The results of the experiment with 3 MUF-substrates are listed in Table 3.

The results show that the decomposition of MUFsubstrates depends on the concentration of active agents in the water sample. Whether these active agents are derived predominantly from free enzymes or from living organisms was investigated with size fractionated water samples.

\section{Enzyme kinetics of MUF-substrates}

Varying amounts of MUF-substrates (MUF- $\alpha$-Dglucoside, MUF-glucosaminide, MUF-phosphate or MUF-L-leucine) were added to a natural water sample in order to establish substrate saturation curves and Lineweaver-Burk plots of exoenzymatic activities (Fig. 3a-d).

As can be seen from the figures, enzymatic activities on MUF-substrates correspond to saturation kinetics. Hydrolyzation times for naturally occurring organic compounds affected by the enzymes in question are $109 \mathrm{~h}$ for $\alpha$-D-glucosidase, $383 \mathrm{~h}$ (110) for glucosaminidase, $394 \mathrm{~h}(220)$ for phosphatase, and $255 \mathrm{~h}$ for protease. Values in parentheses were calculated from hydrolyzation times of the lowest substrate additions in cases where they did not fit the regression line. Max-

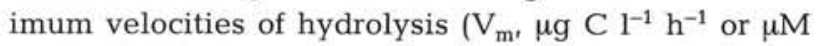
$\mathrm{PO}_{4}{ }^{3-} \mathrm{l}^{-1} \mathrm{~h}^{-1}$ ) were 0.26 (glucose), 2.30 (glucosamine),
0.063 (phosphate), and 5.08 (leucine). These investigations were made at low ambient water temperature $\left(4^{\circ} \mathrm{C}\right)$ in early spring. Comparisons with maximum uptake velocities and turnover rates of the same ${ }^{14} \mathrm{C}$ labelled organic substrates by bacteria suggest that these organic nutrients are supplied with a much higher maximum velocity of hydrolysis but a lower hydrolyzation rate to the DOC pool. The importance of this observation for the balance of the pool of macromolecular organic matter and the DOC pool is discussed later.

\section{Experiments with size fractionated water samples}

The origin of exoenzymes in a water sample can be manifold. Dissolved enzymes may be present in the sample prior to addition of MUF-substrates. Exoenzymes acting on MUF-substrates and their natural analogues may, also, be produced by different kinds of organisms in the sample. Enzymes produced by such organisms may be distributed in the water or operate in close contact with the cells. Furthermore, dissolved enzymes may become adsorbed to particle surfaces or inactivated by complexing agents.

The experiments described here are designed for the determination of the activities of free dissolved enzymes and for the localization of the most active particle size fraction. In enzymatic studies size fractionation via filtration is, of course, a critical approach. Contrary to radiotracer uptake experiments, in which destruction of cells causes only a minor loss of labelled material in the filtration process after incubation, exoenzymatic experiments necessitate prefiltration and enzymes set free from the cells may operate throughout the incubation period. Filtration should, therefore, be done with extreme caution, avoiding any vacuum pressure with filters of pore sizes of $3 \mu \mathrm{m}$ or greater and using very low vacuum pressure with the smaller pore sizes.

Since exoenzymes may be considered to be loosely 

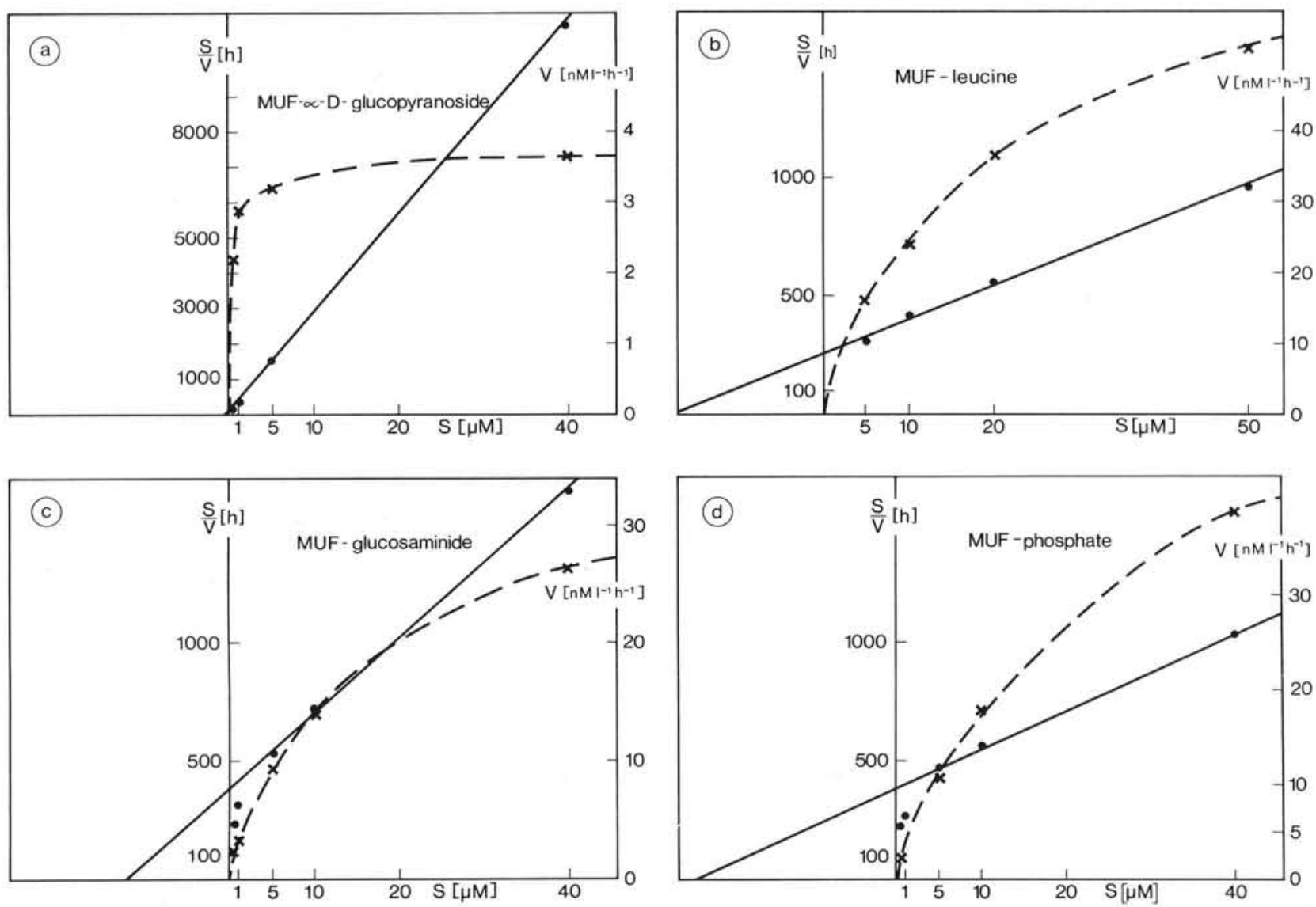

Fig. 3 (a-d). Substrate saturation curves and Lineweaver-Burk plots of exoenzymatic activities

arranged on particle surfaces, shearing forces occurring during the filtration process may cause liberation of exoenzymes and thus, lead to errors in size fractionation experiments. Initial results of enzymatic activity measurements obtained from differential filtration with Nuclepore filters are given in Table 4.

For phosphatase and protease the lowest activities were observed in the sterile $0.2 \mu \mathrm{m}$ filtrate. For phosphatase highest activities were found in the 3 to $8 \mu \mathrm{m}$ particle fraction which is dominated by particle adherent bacteria and nanoplankton. Enzymatic activities on glucosaminides were restricted to $<0.2 \mu \mathrm{m}$ and the bacteria size class 0.2 to $0.6 \mu \mathrm{m}$. Exoproteases were characteristic of the small bacteria size classes $(0.2$ to
$1 \mu \mathrm{m})$ and also of the large particle and plankton size classes 8 to $20 \mu \mathrm{m}$. Since the origin of exoenzymatic activity is a very complex problem, the presented measurements are only representative of the specific water sample (Kiel Fjord) used in the experiment and should not be generalized.

\section{Temperature dependency of exoenzymatic activity}

A short experiment was designed to confirm temperature dependency of exoenzymatic activities of natural water samples. The sample from the Kiel fjord had an in situ temperature of $4{ }^{\circ} \mathrm{C}$ and was incubated at $4{ }^{\circ} \mathrm{C}$ and $20^{\circ} \mathrm{C}$ with additions of $10 \mu \mathrm{M}$ of MUF-phosphate

Table 4. Exoenzymatic activities of different size classes of a natural water sample obtained after prefiltration of sub-samples through the various Nuclepore filters and by subtraction. The results are given as fluorescence emission at $445 \mathrm{~nm}$

\begin{tabular}{|lccccccc|}
\hline \multicolumn{1}{c}{ Enzymes } & Unfiltered & $<0.2$ & $0.2-0.6$ & $0.6-1$ & $1-3$ & $3-8$ & $8-20 \mu \mathrm{m}$ \\
\hline MUF-phosphate & 3.31 & 0.14 & 0.54 & 0.16 & - & 1.67 \\
MUF-glucosaminide & 0.70 & 0.30 & 0.15 & - & - & - \\
MUF-L-leucine & 4.53 & 0.26 & 1.38 & 0.74 & - & - \\
\hline
\end{tabular}


and MUF- $\beta$-D-glucopyranoside. The results are presented in Fig. 4.

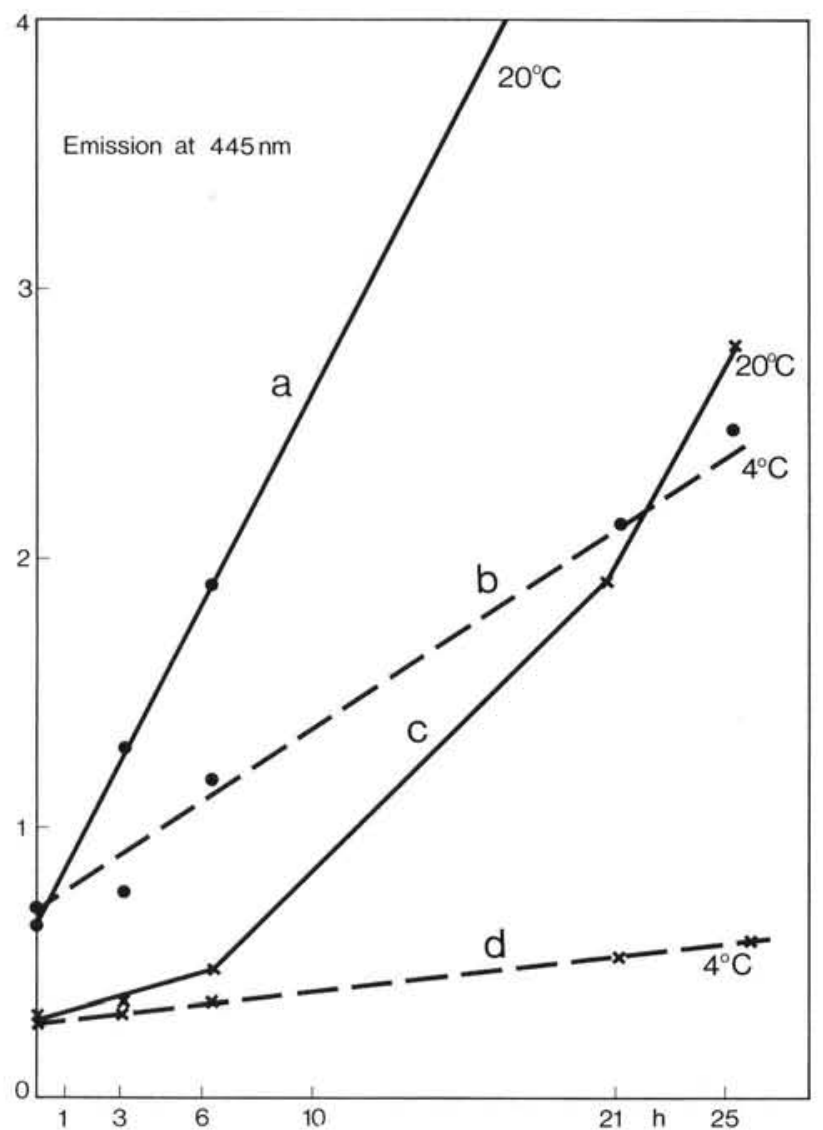

Fig. 4. Influence of incubation temperature on exoenzymatic activities. a: MUF-phosphate $\left(20^{\circ} \mathrm{C}\right)$; b: MUF-phosphate $\left(4^{\circ} \mathrm{C}\right)$; c: MUF- $\beta$-D-glucopyranoside $\left(20^{\circ} \mathrm{C}\right)$; d: MUF- $\beta$-Dglucopyranoside $\left(4^{\circ} \mathrm{C}\right)$. Exoenzymatic activities calculated from linear part of the curves: 0.027/0.011 (MUF-phosphate, $\mu \mathrm{M} \mathrm{P}^{-1} \mathrm{~h}^{-1}, 20 / 4{ }^{\circ} \mathrm{C}$ ) and $0.329 / 0.122$ (MUF- $\beta$-D-glucopy-

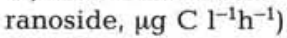

MUF-phosphatase activities show a linear increase over the incubation period which was repeatedly demonstrated even at longer incubation times. The relation of activities at 20 and $4{ }^{\circ} \mathrm{C}$ was $2.6: 1$. MUF- $\beta$ D-glucosidase activities were lower than those of MUF-phosphatase. At $20^{\circ} \mathrm{C}$ an accelerating increase of activity was measured after ca. $7 \mathrm{~h}$ incubation, while the activity at $4{ }^{\circ} \mathrm{C}$ (parallel) remained constant. However, in other experiments at low temperatures disproportionally large increases of MUF- $\beta$-D-glucosidase activity were found. The proportion between activities at 20 and $4{ }^{\circ} \mathrm{C}$ was $2.7: 1$. Temperature response of different exoenzymes appears to be rather similar when the findings from this experiment are considered. More investigations, however, are needed to confirm this statement.

\section{Exoenzymatic activities in relation to other ecological factors}

Field observations were obtained from a $\beta$ mesohaline eutrophic, enclosed fjord (Schlei) and from a $\alpha$-mesohaline less eutrophic fjord with a wide opening into the Baltic Sea (Kieler Förde) during a winter and early spring situation (water temperatures 4 and $6{ }^{\circ} \mathrm{C}$ ). Because enzymatic activity was discovered to be linked mainly to small particles fractions, $<8 \mu \mathrm{m}$, bacteriological parameters were especially investigated for comparison. The phytoplankton population seemed to be in healthy condition and little detritus was present in the water samples. Effects of cell lysis on the enzymatic capacity are therefore considered as not important. The results of a survey from the inner Kiel Fjord to the open Kiel Bight are presented in Table 5.

Highest velocities of hydrolysis and hydrolyzation rates were obtained in the inner fjord, which was characterized by comparatively high values for bacteria numbers, biomass and production as well as chlorophyll a content. Exoenzymatic activities decreased more or less regularly as one approached the open sea. Leucine protease activity showed a reduction of $57 \%$, which was the slightest decline of the investigated enzymes. The same observation was made in the enclosed Schlei fjord. The extent of this reduction is about the same as the decrease in number and biomass of bacteria ( $60 \%$ and $56 \%$, respectively). For phosphatase activity a reduction of $61 \%$ was observed. $\beta$-D-glucosidase decreased by $65 \%$, while $\alpha$-D-glucosidase and glucosaminidase showed the lowest activity in offshore stations $(89 \%$ and $90 \%$ decrease, respectively, in comparison to the inshore values).

Highest hydrolyzation rates were obtained for leucine substrates at all stations. In offshore stations glucosamine compounds showed the lowest hydrolyzation rates. $\alpha$-D-glucoside compounds, however, were hydrolyzed to a much greater extent, although activity of both enzymes is very similar (station Kieler Bucht Mitte). For the hydrolyzation rate of organic phosphorous compounds no clear tendency could be detected.

Values of exoenzymatic activity and accompanying parameters from the strongly eutrophic Schlei fjord are presented in Table 6. It is clearly recognizable from the data that exoenzymatic activities in the enclosed fjord water are much higher than in adjacent offshore stations. This also holds true for the bacteriological and phytoplanktological parameters measured. When comparing the innermost station (Große Breite) with the following station (Missunde), different tendencies of enzymatic activities can be observed. While $\alpha$-Dglucosidase, glucosaminidase and phosphatase activities decreased, a remarkable increase in protease 
Table 5. Exoenzymatic activities, chlorophyll $a$ and accompanying microbial parameters from Kiel fjord (29.-30. 3. 1982). The line between Laboe and Feuerschiff divides the stations of the inner fjord (on the left side) from offshore stations. Exoenzymatic activities are presented as $\mathrm{V}_{\mathrm{m}}$ of substrate liberation (glucose, glucosamine, phosphate, leucine) from MUF-substrate ( $\mu \mathrm{g} \mathrm{Cl} \mathrm{l}^{-1} \mathrm{~h}^{-1}$ or $\mu \mathrm{g} \mathrm{PO}_{4}{ }^{3-} \mathrm{l}^{-1} \mathrm{~h}^{-1}$, first value). The hydrolyzation rate of naturally occurring substrate analogues is also presented (\% $\mathrm{h}^{-1}$, second value)

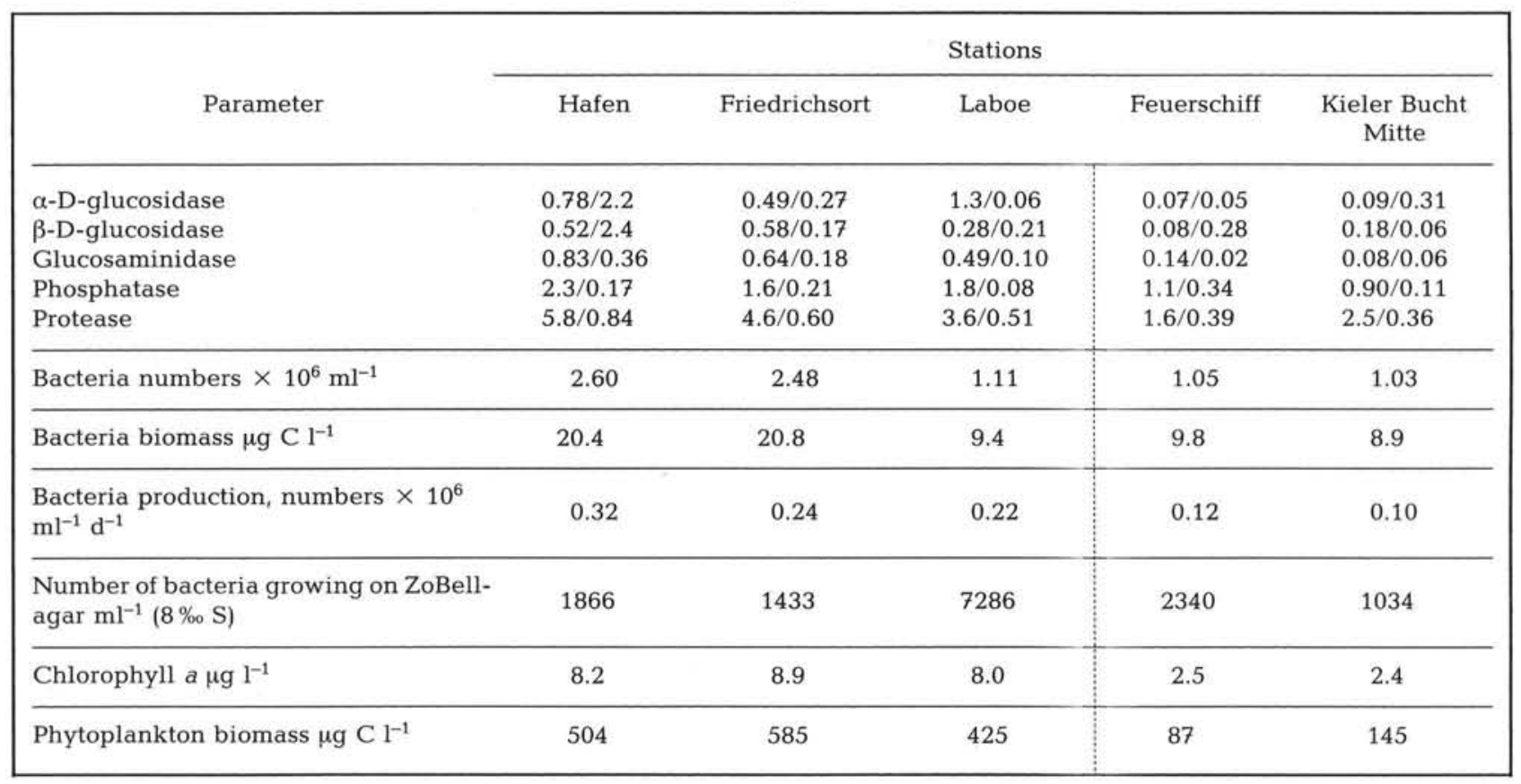

activity was obvious. From the bacteriological data only bacteria production and saprophyte counts showed a similar increase at this station in contrast to total bacteria numbers and biomass. This suggests that predominantly active bacteria are closely related with protease activity and that autoradiography (Hoppe, 1977) may be an appropriate tool for verification of this hypothesis.

Hydrolyzation rates of naturally occurring substrate analogues are much lower in offshore stations than in

Table 6. Exoenzymatic activities, chlorophyll $a$ and accompanying microbial parameters from the Schlei fjord (28.-29. 4. 82).

Dashed line divides stations of fjord area from adjacent offshore stations. For further explanation see legend to Table 5

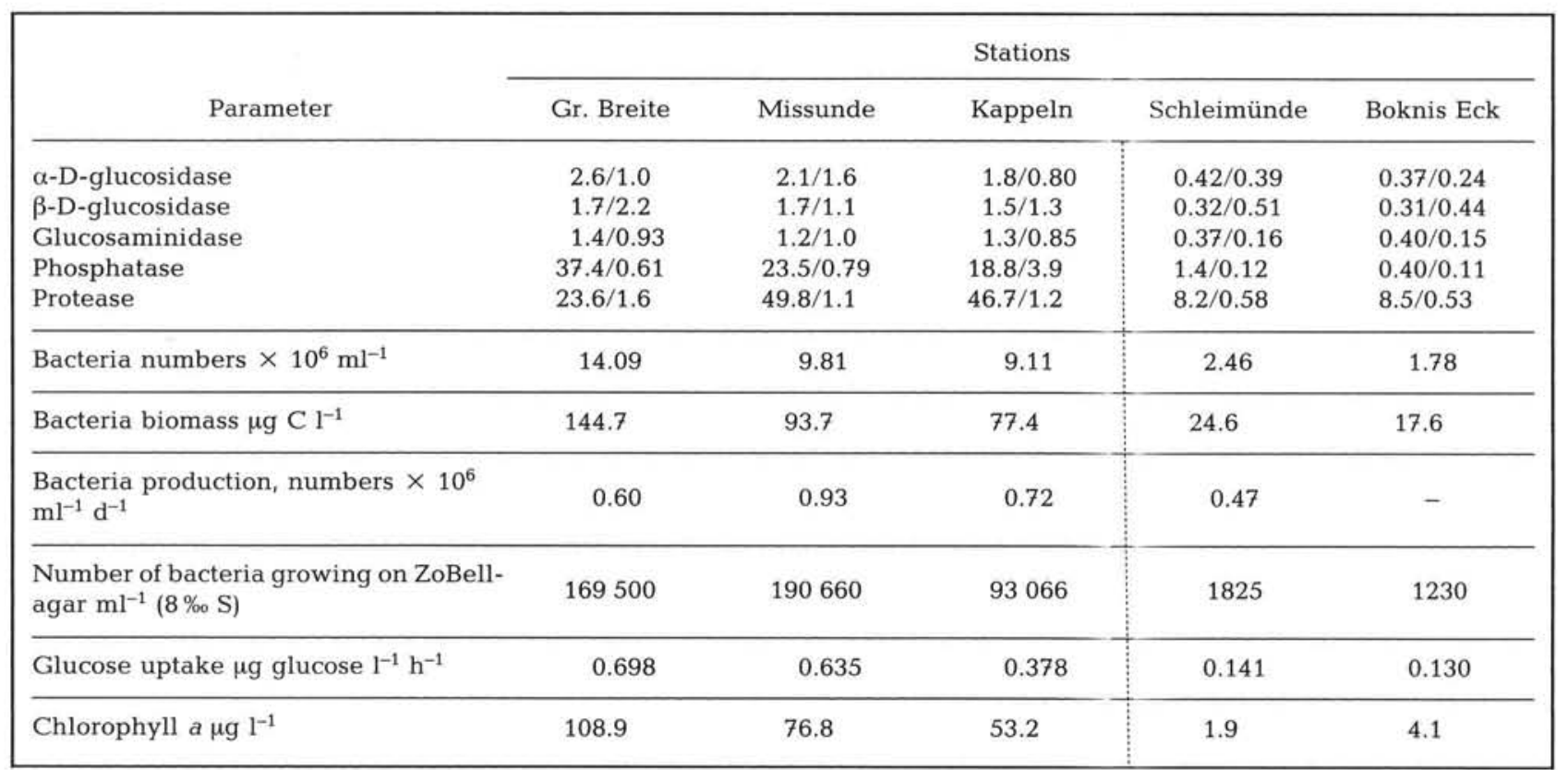


fjord stations, especially for organic phophorous compounds and glucosamine compounds. Generally, hydrolyzation rates appear to be relatively low in contrast to the high values for exoenzymatic potentials (velocities of hydrolysis). It cannot presently be determined whether this is due to high, natural substrate concentrations or to low affinity of exoenzymes under natural conditions.

If the results of the 2 fjord investigations are compared, it becomes obvious that exoenzymatic potentials are considerably (ca 5 times) higher in the strongly eutrophied Schlei fjord. On the other hand bacteria numbers and biomasses are also much higher in the Schlei fjord than in the Kiel fjord and there is a greater abundance of bacteria und bacterical activity in offshore stations as well. However, the relation between bacteria numbers of the 2 investigations does not exactly reflect the differences in exoenzymatic activities. While bacteria numbers and biomass are about 4 times higher at Schlei stations (Kappeln, Missunde) than at Kiel fjord stations (Hafen, Friedrichsort), the relations of protease activity is $9.3: 1$, and that of $\alpha$ and $\beta$-D-glucosidase activity is about $3: 1$ for both substrates. The relation of phosphatase activity between these stations is $11: 1$. These calculations would suggest that special fjord conditions, e.g. high standing stock of phytoplankton and saprophytic bacteria (c. f. Table 5 and 6) together with total bacteria numbers and related parameters will be reflected by a characteristic pattern of enzymatic activities. The decomposition of protein and organic phosphorous compounds are especially favoured by these conditions, while the difference of carbohydrate decomposition only reflects the increase in bacteria abundance.

At the offshore stations (Boknis Eck, Feuerschiff) another observation was made. The relation of bacteria between the 2 stations was about $2: 1$, but the relation of $\alpha$ - and $\beta$-glucosidase, phosphatase and protease activity were $5.3: 1,3.9: 1,0.4: 1$ and $5.3: 1$, respectively. This means that in less eutrophic waters protein, as well as carbohydrate decomposition, is stimulated by changing environmental conditions thus attaining a strikingly similar order of magnitude. Because hydrographical conditions at the offshore stations during the 2 investigations were similar, this observation should mainly reflect a time trend. Phosphatase activity, however, decreased in relation to bacteria numbers. This may be an effect of the lack of available substrate or, simply of a lesser dependence of phosphatase activity on bacteria development.

\section{DISCUSSION}

Application of exoenzymatic techniques to marine ecological studies is relatively new. Only a few investi- gations, mainly on exoenzymatic decomposition of particulate organic matter, have been undertaken in recent years (Reichardt, 1973; Little et al., 1979; Meyer-Reil, 1981). Phosphatase activity in lake water has been determined with MUF-phosphate as a substrate by Pettersson and Jansson (1978).

There is thus little experience with exoenzymatic methodology and its adaptation to aquatic in situ conditions and, much more importantly, there are no further approaches to supplementary investigations which might support interpretation and understanding of enzymatic measurements. Typical investigations, therefore, have employed a more or less conventional set of experiments, as is also done in this study. Because a considerable fraction of total enzymatic activity was registrated in the small size classes below $8 \mu \mathrm{m}$, a fuller understanding through the co-investigation of bacteriological parameters appears to be promising. The biomass and production of bacteria especially, seem to have a close relationship to some of the enzymatic activities measured, but the number of data up till now is too small to establish a clear correlation. Of the approximately 15 to $30 \%$ of the yearly primary production which is transformed to bacterial biomass in the study area (Rheinheimer, 1981), a considerable fraction should undergo exoenzymatic decomposition prior to incorporation by bacteria.

Drastic changes in environmental conditions characteristic of the transition zone between the enclosed eutrophic fjord and offshore stations are followed by strong decreases in exoenzymatic potentials in the Kiel fjord. The hydrolyzation rates, however, may not necessarily follow the pattern of velocity of hydrolysis $\left(V_{m}\right)$. Notedly, for the hydrolyzation rate of organic phosphorous compounds and, to some extent, for protease activity an increase or only a slight decrease was observed in the less eutrophic offshore areas. Strongest decreases for both parameters $\left(\mathrm{V}_{\mathrm{m}}\right.$ and hydrolyzation rate) were measured for $\alpha$-D-glucosidase and glucosaminidase activities, which gives a hint as to their usefulness in tracing effects of pollution and/or eutrophication.

A somewhat different situation was found in the Schlei fjord during the spring bloom of phytoplankton. Exoenzymatic activities $\left(\mathrm{V}_{\mathrm{m}}\right.$ and hydrolyzation rate) are much higher than in the Kiel fjord even when the offshore stations of both regions - less influenced by special environmental conditions than the fjord stations - are compared. Activities $\left(\mathrm{V}_{\mathrm{m}}\right)$ generally increased about 2 to 5 times at offshore stations and 2 to 10 times at fjord stations.

Highest enzymatic activities $\left(V_{m}\right)$ in the Schlei fjord were measured for protease and phosphatase. $\alpha-D$ glucosidase and phosphatase activity show the strongest decline from fjord towards offshore stations. 
On the other hand, measurements of glucosaminidase activity are lower than $\alpha$-and $\beta$-D-glucosidase activity at the Schlei fjord stations and they do not decrease as much as at the offshore stations, as was found during the Kiel fjord investigation. This may be attributed to the specific conditions of the 2 fjords, one of which is strongly influenced by terrestrial runoff (Schlei fjord) and the other, depending on the prevailing hydrographic situation, by marine waters. This means that the supply of hydrolyzable nutrients may be divided into allochthonous and autochthonous sources and, thus, establish a specific pattern of enzymatic activities for the different fjord systems. Most of the interpretations about exoenzymatic activity measurements are still hypothetical in character due to the lack of adequate supporting co-investigations. The main investigative objective of the method is that it offers a tool to follow the subsequent decomposition of macromolecular organic materials into large and small molecular nutrients and its fate in the food chain or its introduction into the DOC pool.

For further studies it seems promising to combine radiotracer uptake experiments with fluorescent enzymatic methods.

Somville and Billen (in press) have shown that there exists a close relationship between protease activity and amino-acid uptake in a variety of aquatic biotopes. This trend was also observed in our glucosidase, protease and glucosaminidase measurements in the Kiel fjord and corresponding values of ${ }^{14} \mathrm{C} /{ }^{3} \mathrm{H}$-glucose, ${ }^{14} \mathrm{C}$ asparagine $/{ }^{3} \mathrm{H}$-leucine and ${ }^{14} \mathrm{C}$ glucosamine uptake by

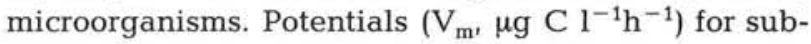
strate uptake in the Kiel fjord during March have been found to be 0.03 for leucine, 0.1 for glucose and 0.06 for glucosamine (Gocke, 1978; Hoppe, 1978). If these values are compared with those of enzymatic activity, it becomes obvious that much more substrate may be liberated from substrate compounds than is immediately incorporated by bacteria. The hydrolyzation rate of substrate compounds, however, is lower than the turnover rate $\left(\% \mathrm{~h}^{-1}\right)$ of the corresponding substrates (leucine 10.3, glucose 5.8, glucosamine 0.18 ) via substrate uptake. As a preliminary approach to this problem, a combined experiment of leucine hydrolyzation from a fluorescent compound and leucine incorporation from the DOC pool was conducted. This experiment is described and discussed here briefly in order to give an outlook on the possible design of extended studies. A compilation of the results is as follows:

(A) Liberation of leucine in a natural water sample from the Kiel fjord, supplemented with $36 \mu \mathrm{g} \mathrm{Cl}^{-1}$ MUF-leucine: $3.5 \mu \mathrm{g} \mathrm{C}^{-1} \mathrm{~h}^{-1}$.

(B) Uptake kinetics of ${ }^{3} \mathrm{H}$-leucine (5 concentrations: from $0.0047 \mu \mathrm{g} \mathrm{C}^{-1}$ leucine to $10.0047 \mu \mathrm{g} \mathrm{C}^{-1}$ leucine, imposed of $0.0047 \mu \mathrm{g} \mathrm{C}^{3} \mathrm{H}$-leucine plus up to $10 \mu \mathrm{g} \mathrm{C}$ unlabelled leucine) from the same water sample as used in (A): $V_{m}=0.129 \mu \mathrm{g}$ $\mathrm{Cl}^{-1} \mathrm{~h}^{-1}, \mathrm{~T}_{\mathrm{t}}=107 \mathrm{~h}, \mathrm{~K}_{\mathrm{t}}+\mathrm{S}_{\mathrm{n}}=13.9 \mu \mathrm{g} \mathrm{C \textrm {l } ^ { - 1 }}$.

(C) Uptake kinetics of ${ }^{3} \mathrm{H}$-leucine (5 concentrations: from $0.0047 \mu \mathrm{g} \mathrm{C} \mathrm{l}^{-1}$ leucine to $10.0047 \mu \mathrm{g} \mathrm{C} \mathrm{l}^{-1}$ leucine, composed of $0.0047 \mu \mathrm{g} \mathrm{C}^{3} \mathrm{H}$-leucine plus up to $10 \mu \mathrm{g} C$ unlabelled leucine) from the same water sample as used in (A) and (B) supplemented with the same amount of MUF-leucine as used in (A): $V_{m}=0.124 \mu \mathrm{g} \mathrm{Cl}^{-1} \mathrm{~h}^{-1}, \mathrm{~T}_{\mathrm{t}}=165 \mathrm{~h}, \mathrm{~K}_{\mathrm{t}}+\mathrm{S}_{\mathrm{n}}=$ $20.4 \mu \mathrm{g} \mathrm{C}^{-1}$.

(D) In the combined experiment (C) $10926 \mathrm{cpm}$ were obtained at the substrate concentration $0.0047 \mu \mathrm{g}$ $\mathrm{C}^{-1}{ }^{3} \mathrm{H}$-leucine plus $36 \mu \mathrm{g} \mathrm{C} \mathrm{l}^{-1}$ MUF-leucine.

In the radiotracer experiment (B) $11034 \mathrm{cpm}$ were obtained at the substrate concentration of 0.0047

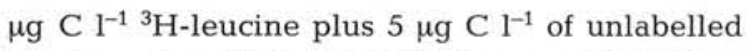
leucine. $\mathrm{V}$ at this concentration was $0.0339 \mu \mathrm{g}$ $\mathrm{C}^{-1} \mathrm{~h}^{-1}$.

This experiment was not totally satisfactory when greater amounts of MUF-leucine than used here were applied in the combined experiment. It turns out that the sample supplemented with $0.0047 \mu \mathrm{g} \mathrm{C}^{-1}{ }^{3} \mathrm{H}$ leucine plus $36 \mu \mathrm{g} \mathrm{Cl}^{-1}$ of MUF-leucine behaves in the same fashion as a parallel supplemented with $0.0047 \mu \mathrm{g} \mathrm{C}^{-1}{ }^{3} \mathrm{H}$-leucine plus $5 \mu \mathrm{g} \mathrm{C}^{-1}$ of cold leucine. This amount of cold leucine is present in the water sample at the start of incubation (B), while (C) supplemented with MUF-leucine the cold leucine component is continuously increasing from the 0 -level during incubation due to the exoenzymatic splitting of the compound. Consequently, more leucine must be set free from the MUF-leucine as suggested by the comparison with (B) $\left(5 \mu \mathrm{g} \mathrm{Cl}^{-1}\right)$. This becomes evident from the comparison of $K_{t}+S_{n}$ values from (B) and (C). The difference between them is $6.5 \mu \mathrm{g} \mathrm{C}$, which should be the true concentration of leucine $\mathrm{C}$ liberated from the fluorescent leucine compound during incubation. Nevertheless, the system reacts with approximately the same activity as in the sample supplemented with $0.0047 \mu \mathrm{g} \mathrm{C} 1^{-1}{ }^{3} \mathrm{H}$-leucine and $5 \mu \mathrm{g} \mathrm{C} 1^{-1}$ cold leucine, and the uptake velocity at this concentration is $0.0339 \mu \mathrm{g} \mathrm{C} \mathrm{l^{-1 } \mathrm { h } ^ { - 1 }}$ (D). This implies that uptake of leucine hydrolyzed from the flourescent compound has about the same value, and this is considerably smaller than the total input of leucine into the DOC pool via hydrolyzation (A).

Several questions arise from this experiment. For example, why is there a descrepancy between direct measurement of MUF-leucine hydrolysis (A) and the results of changes in $\mathrm{K}_{\mathrm{t}}+\mathrm{S}_{\mathrm{n}}$ (B and C)? But, also, why is there a high velocity of hydrolysis and only a relatively slow uptake of the hydrolyzed compounds by living organisms (e.g. heterotrophic bacteria)?

Observations suggest that the products of exoenzy- 
matic hydrolyzation of macromolecules are only partly taken up by microheterotrophs during their growth. A certain amount would enter the DOC pool and serve as food mainly for free living bacteria or undergo further chemical conversion. However, this finding resulted from a substrate addition which may be relatively high in comparison to natural conditions. With substrate concentrations more representative of natural conditions a better equilibrium between exoenzymatic input and heterotrophic output from the DOC pool may be expected.

Acknowledgements. This investigation was supported by the Ministry of Research and Technology, Bonn, FRG, Project: MFU 0506/9. I would like to thank K. Gocke and G. Rheinheimer for critical review of the manuscript, and Miss S. Bauerfeind for provision of heterotrophic substrate uptake data. Gratitude is further expressed to T. Noji for correcting the English manuscript and Miss R. Koppe and W. Lucassen for invaluable assistance with the experiments.

\section{LITERATURE CITED}

Berman, T., Holm-Hansen, O. (1974). Release of photoassimilated carbon as dissolved organic matter by marine phytoplankton. Mar. Biol. 28: 305-310

Burns, R. G. (1980). Microbial adhesion to soil surfaces: consequences for growth and enzymatic activities. In: Berkeley, R. C. W., Lynch, J. N., Melling, J., Rutter, P. R., Vincent, B. (eds.) Microbial adhesion to surfaces. Chapter 14. Published for the Society Chemical Industry, London, p. 249-262

Corpe, W. A., Winters, H. (1972). Hydrolytic enzymes of some periphytic bacteria. Can J. Microbiol. 18: 1483-1490

Derenbach, J. B., LeB. Williams, P. J. (1974). Autotrophic and bacterial production: fractionation of plankton populations by differential filtration of samples from the English Channel. Mar. Biol. 25: 263-269

Eppley, R. W., Horrigan, S. G., Fuhrman, J. A., Brooks, E. R., Price, C. C., Sellner, K. (1981). Origins of dissolved organic matter in southern California coastal waters: experiments on the role of zooplankton. Mar. Ecol. Prog. Ser. 6: 149-159

Fuhrman, J. A., Azam, F. (1980). Bacterioplankton secondary production estimates for coastal waters of British Columbia, Antarctica, and California. Appl. environ. Microbiol. 39: 1085-1095
Gocke, K. (1978). Untersuchungen über den Jahreszyklus der heterotrophen Aktivität in der Kieler Förde. Arch. Hydrobiol. 82: 123-141

Hoppe, H.-G. (1977). Analysis of active bacteria populations. In: Rheinheimer, G. (ed.) Microbial ecology of a brackish water environment. Springer, Berlin, p. 179-197

Hoppe, H.-G. (1978). Relations between active bacteria and heterotrophic potential in the sea. Neth. J. Sea Res. 12: 78-98

Leaback, D. H., Walker, P. G. (1961). Studies on glucosaminidase. 4. The fluorimetric assay of $\mathrm{N}$-acetyl- $\beta$ glucosaminidase. Biochem. 7: 151-156

Little, J. E., Sjogren, R. E., Carson, G. R. (1979). Measurement of proteolysis in natural waters. Appl. environ. Microbiol. 37: 900-908

Meyer-Reil, L.-A. (1981). Enzymatic decomposition of proteins and carbohydrates in marine sediments: methodology and field observations during spring. Kieler Meeresforsch., Sonderh. 5: 311-317

Meyer-Reil, L.-A., Bölter, M., Dawson, R., Liebezeit, G., Szwerinski, H., Wolter, K. (1980). Interrelationships between microbiological and chemical parameters of sandy beach sediments, a summer aspect. Appl. environ. Microbiol. 39: 797-802

Pancholy, S. K., Lynd, J. Q. (1971). Microbial esterase detection with ultraviolet fluorescence. Appl. Microbiol. 22: 939-941

Pancholy, S. K., Lynd, J. Q. (1972). Quantitative fluorescence analysis of soil lipase activity. Soil Biol. Biochem. 4: 257-259

Petterson, K., Jansson, M. (1978). Determination of phosphatase activity in lake water - a study of methods. Verh. int. Verein. theor. angew. Limnol. 20: 1226-1230

Reichardt, W. (1973). Das Reaktionspotential im Ókosystem. Zur Problematik limnologischer Enzymanalysen. Arch. Hydrobiol. 42 (Suppl.): 253-272

Rheinheimer, G. (1981). Investigations on the role of bacteria in the food web of the Western Baltic. Kieler Meeresforsch., Sonderh. 5: 284-290

Rosenthal, A. L., Saifer, A. (1973). Continuous UV monitoring of fluorogenic substrates. I. Kinetics analysis of $\mathrm{N}$-acetyl$\beta$-D-hexosamimidases. Analyt. Biochem. 55: 85-92

Somville, M., Billen, G. (in press). A method for determining exoproteasic activity in natural waters. Limnol. Oceanogr.

Taylor, D. G., Williams, V. M., Crawford, N. (1977). Bis- (-4Methyl-umbelliferyl) phosphate as a substrate for the surface membrane-associated phosphodiesterase activity of pig platelets. Biochim. Biophys. Acta 465: 667-671

Wolter, K. (1982). Bacterial incorporation of organic substances released by natural phytoplankton populations. Mar. Ecol. Prog. Ser. 7: 287-295

Zimmermann, R., Meyer-Reil, L. A. (1974). A new method for fluorescence staining of bacteria populations on membrane filters. Kieler Meeresforsch. 30: 24-27 